\title{
Oligohydramnios-Induced Lung Hypoplasia: The Influence of Timing and Duration in Gestation
}

\author{
ADRIEN C. MOESSINGER, MARGARET H. COLLINS, WILLIAM A. BLANC, HENRY R. REY, \\ AND L. STANLEY JAMES \\ The Divisions of Perinatal Medicine and Developmental Pathology, Departments of Pediatrics and Pathology, \\ College of Physicians and Surgeons, Columbia University, New York, New York 10032
}

\begin{abstract}
We drained amniotic fluid for periods of 5 and 10 days at various times in gestation between days $\mathbf{4 0}$ and 55 in the guinea pig (term is 67 days). We analyzed the impact of this procedure on fetal lung growth and used untouched littermate fetuses as controls. During the canalicular stage of lung development, total lung DNA per gram of fetal weight was significantly reduced after only 5 days of oligohydramnios and the percent change did not vary between the two consecutive 5 -day periods studied (period A, days 40 to $45, \delta$ of $-0.047 \mathrm{mg}, p=0.004$; period $B$, days 45 to $50, \delta$ of $-0.042 \mathrm{mg}, p=0.002$ ). The impact of the same duration of oligohydramnios on lung growth later in gestation, during the terminal sac stage of lung development, was less (period C, days 50 to $55, \delta$ of $\mathbf{- 0 . 0 2 7}$ $\mathrm{mg}, p=0.097)$. This reduction in effect between period $A$ or $B$ and $C$ was significant at the 0.05 level using a oneway analysis of variance. Two overlapping 10-day periods were also studied. In both experiments, the percent changes in lung DNA per gram of fetal weight between experimental and littermate controls were significant (period $D$, days 40 to $50, \delta$ of $-0.072 \mathrm{mg}, p=0.001$; period $\mathrm{E}$, days 45 to $55, \delta$ of $-0.047 \mathrm{mg}, p=0.001$ ). The inhibitory effect of oligohydramnios on lung growth was more marked in period $\mathrm{D}$ than $\mathrm{E}$ (significant at the 0.05 level). A two-way analysis of variance indicated that the magnitude of the changes was related to both the time of onset and the duration of oligohydramnios. We conclude that even a short period of oligohydramnios interferes with lung development, and that the extent of this interference depends to a large extent on the time of onset and to a lesser extent on the duration of oligohydramnios. Irrespective of duration, the greatest effects were observed during the canalicular stage of lung development. (Pediatr Res 20: 951-954, 1986)
\end{abstract}

In recent years, congenital lung hypoplasia has become a common pathological finding in perinatal deaths (1). The emergence of lung hypoplasia at autopsy results mainly from a decrease, through improved prevention and treatment, in the incidences of previously more common pulmonary pathologies such as severe meconium aspiration, congenital pneumonia, and hyaline membrane disease (2). Multiple congenital malformations are found in the majority of infants with lung hypoplasia, i.e. diaphragmatic hernia, renal anomalies, right-sided cardiac lesions, and musculoskeletal disorders (3). However, lung hypo-

Received March 10, 1986; accepted April 21, 1986.

Reprint address Adrien C. Moessinger, M.D., Babies Hospital, Box 34, 3959 Broadway, New York, NY 10032.

This work was supported by NIH Grant HL-14218. plasia is also found as an isolated anomaly $(3,4)$ or in association with minor deformities compatible with survival, i.e. oligohydramnios deformation sequence following prolonged rupture of the fetal membranes (5).

Over 20 years ago, both Blanc et al. (6) and Bain et al. (7) demonstrated, using perinatal autopsy data, that prolonged oligohydramnios, irrespective of its cause, was associated with fetal lung hypoplasia. More recently, experimental evidence derived from work in various mammalian species confirmed this association (8-11). Two important questions remain unanswered: 1) what is the mechanism by which lack of amniotic fluid interferes with fetal lung growth? 2) What are the influences of both gestational age at the onset of oligohydramnios, and its duration, on the degree of lung hypoplasia? This report focuses on the latter question using the guinea pig model of oligohydramnios. A preliminary account of these experiments has been published previously (12).

\section{MATERIALS AND METHODS}

Fetal lung growth proceeds in three consecutive stages, i.e. the pseudoglandular, canalicular, and terminal sac stages. Although this sequence is invariable, its timing in gestation varies among species. We induced oligohydramnios between days 40 and 55 of gestation in the guinea pig, a period roughly corresponding to 18 to $29 \mathrm{wk}$ of gestation in the human. The five time-frames studied are illustrated in Figure 1, along with the stages of fetal lung development involved. More specifically, the experiments were as follows: experiment A: drainage between days 40 and 45 ( 5 days); experiment B: drainage between 45 and 50 ( 5 days); experiment $C$ : drainage between days 50 and 55 ( 5 days); experiment D: drainage between days 40 and 50 (10 days); experiment E: drainage between days 45 and 55 (10 days).

All fetuses were sacrificed at the end of the 5- or 10-days study period to assess fetal and lung growth. In order to overcome the effects of variation between litters, we used untouched littermate fetuses as controls. Whenever possible, untouched littermate fetuses located at the same level in the opposite uterine horn were chosen as paired controls in order to control for the naturally occurring intralitter variation in fetal size.

Pregnant guinea pigs (Cavia porcellus, Camm-Hartley strain) were obtained 30 days after mating from the Camm Research Laboratory, Wayne, NJ. Pregnant animals were caged individually and provided with guinea pig chow no. 5025 (Ralston Purina Co.) and tap water ad libitum. Following an overnight fast, the animals were anesthetized with intramuscular injections of ketamine hydrochloride $(40 \mathrm{mg} / \mathrm{kg}$ ) (Ketaset, Bristol Lab.) and acepromazine maleate $(3 \mathrm{mg} / \mathrm{kg}$ ) (Tech America Group, Inc.). After local anesthesia with lidocaine, a midline laparotomy was performed. Both uterine horns were exteriorized and the position of each fetus was recorded. Half the litter was randomly assigned to the experimental group and the other half served as 


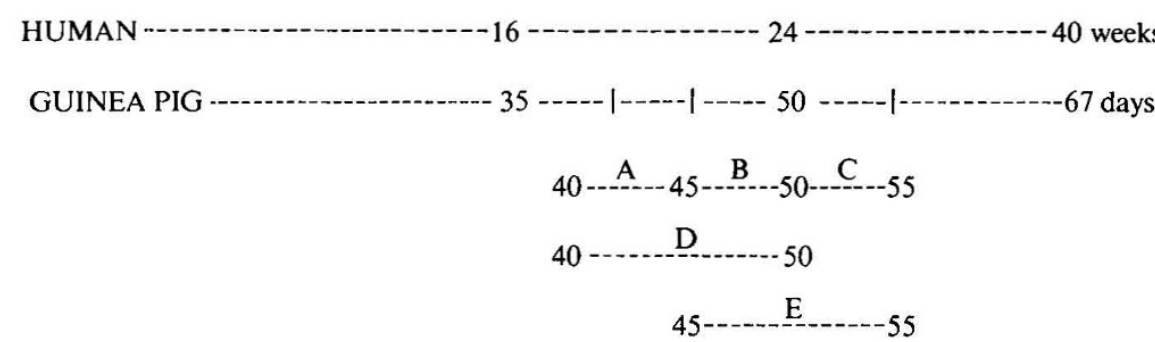

Fig. 1. Comparison of the postembryonic stages of fetal lung development between the human and the guinea pig (13). The bars with letters $A$, $B, C, D, E$ illustrate the time-frames of the various oligohydramnios experiments designated in the text with the same code.

controls (litter size varied between two and six fetuses). We used one to two pairs of fetuses per litter, and the actual distribution is detailed in "Results."

Oligohydramnios was induced by creating an amnioperitoneal fistula as follows. A $0.5-\mathrm{cm}$ incision was made on the antimesometrial side of the uterus. A similar incision was then made in the inverted yolk sac without disrupting the vitelline circulation. At this point the intact amnion, presenting itself through the incision, bulging with amniotic fluid, was pulled and torn with a forceps. This procedure leaves a hole of more than $1 \mathrm{~cm}$ in diameter in the amnion and leads to continued leakage of amniotic fluid to the maternal peritoneal cavity. The maternal abdomen was closed in two layers and the animals returned to their cages. Preoperative daily care was resumed.

On the day of sacrifice, the fetuses were delivered abdominally under Ketamine anesthesia. The uterine horns were inspected and the patency of the amnioperitoneal fistulas was verified. Only fetuses noted to be alive (fetal movements) at the time of laparotomy were used for further analyses. The entire pregnant uterus was excised and placed on ice until cessation of fetal movements. Following drainage of each fetal sac into Petri dishes, the volumes of amniotic fluid were measured to $0.1 \mathrm{ml}$ with a graded syringe. Strictly speaking the fluid drained is not only amniotic in origin; due to the persistence of the inverted yolk sac it contains a small amount of exocoele fluid (14). Only fetuses with a patent uteroperitoneal fistula and no amniotic fluid at the time of sacrifice were considered satisfactory experimental animals and were further processed for analyses. The fetuses were examined, weighed, and measured. They were then dissected on ice and their lung, liver, brain, and placenta were weighed to the nearest $0.1 \mathrm{mg}$ on a Mettler scale. Total lung DNA was extracted according to the method of Munro and Fleck (15) and measured by ultraviolet absorption. Protein content was measured by the Biuret method.

The values for body and organ weights and biochemical results were entered into a computer data base. Following data verification steps, the statistical analysis proceeded in two stages. During the preliminary phase, descriptive statistics were generated for each of the variables recorded. These included means and SDs over each of the five sets of experiments for all the animals studied. This step was used to assess whether the data were uniformly distributed and to compare our values with those of others. During this preliminary phase, initial comparisons of differences between control and experimental fetuses were performed using two sample $t$ tests. Because of the relatively small number of animals studied (approximately five to six pairs per experiment), the large number of variables available, and the results of the preliminary analysis, we decided to restrict the secondary analysis to a single parameter, total lung DNA per gram of fetal weight. This ratio was chosen since it reflects lung cell number, corrected for fetal size, and is thus a good index of lung growth. During this secondary phase of data management, one- and two-way analyses of variance were used to assess whether the magnitude of the effect of oligohydramnios on lung growth was related to the onset of the oligohydramnios (with respect to gestational age of the fetus) and to the duration of the insult, or to some interaction between these two factors.

\section{RESULTS}

Fetal mortality in the form of early abortions was between 30 and $40 \%$, depending on the time of onset of oligohydramnios. However, there was no significant difference in abortion rates over the five time periods of this study. A microscopic examination of the placentas and membranes in a subset of aborted fetuses failed to incriminate infection as a determinant of abortion. Retained fetal deaths were noted in only three instances (two experimental and one control fetuses). All fetuses used for further analyses were alive and well as documented by fetal activity. The mean volumes of amniotic fluid recovered from control fetuses on days 45,50 , and 55 were in keeping with the published data (16) and are shown in Table 1, along with the descriptive statistics on fetal body and organ weights.

Lung weights were consistently and significantly less in the experimental animals following amniotic fluid drainage. In contrast, and with only a single exception (i.e., brain weights in experiment $\mathrm{C}$ ), there were no significant differences in the weights of placenta, liver, and brain between experimental and control fetuses. Similarly, and also with only one exception (i.e. experiment D), there was no appreciable difference in fetal body weights. The weights of several other organs were also recorded (heart, kidney, adrenal, spleen) and are not shown in Table 1 for simplification. There were no significant differences in these values between experimental and control fetuses. Of note, the kidneys of all experimental groups together weighed on the average $96 \%$ of the control values.

The fetal lungs were found to be hypoplastic (less lung DNA per unit of fetal weight) in four of the five experiments. The mean values of this parameter in control and experimental fetuses and the mean differences between the two groups and the results of paired $t$ tests are summarized in Table 2. Except for experiment $C$ (short-term late in gestation), there were significant differences between the values for experimental and control fetuses. The average differences for the short-term experiments were similar in experiments A and B, 0.047 and $0.042 \mathrm{mg}$ respectively, and was reduced to $0.027 \mathrm{mg}$ for experiment $C$. This reduction in effect between experiments $\mathrm{A}$ or $\mathrm{B}$ and $\mathrm{C}$ was found to be significant at the 0.05 level using a one-way analysis of variance. When comparing the results of the two long-term experiments, the effect of oligohydramnios was greater in experiment $\mathrm{D}(\delta=0.072)$ than in experiment $\mathrm{E}(\delta=0.047)$. This difference was significant at the 0.05 level using a one-way analysis of variance. A two-way analysis of variance indicated that the magnitude of the changes in lung DNA was directly related to both the time of onset and the duration of oligohydramnios. However, while the effect of onset was statistically significant $(\mathrm{F}=3.43, p<0.05)$, the effect of duration was not $(\mathrm{F}=1.56, p>0.05)$. 
Table 1. Effect of gestational age and duration of oligohydramnios on fetal growth (mean $+S D)$

\begin{tabular}{|c|c|c|c|c|c|c|c|}
\hline Gestation & & $\begin{array}{l}\text { Amniotic fluid } \\
\text { volume (ml) }\end{array}$ & $\begin{array}{l}\text { Body } \\
\text { (g) }\end{array}$ & $\begin{array}{c}\text { Placenta } \\
(\mathrm{g})\end{array}$ & $\begin{array}{l}\text { Lung } \\
(\mathrm{g})\end{array}$ & $\begin{array}{l}\text { Liver } \\
(\mathrm{g})\end{array}$ & $\begin{array}{c}\text { Brain } \\
\text { (g) }\end{array}$ \\
\hline $\begin{array}{l}\text { Experiment } A \\
\quad 40-45 \text { days ( } n \\
=5 \text { pairs) }\end{array}$ & $\begin{array}{l}\text { Control } \\
\text { Experimental } \\
\% \text { Control } \\
\text { Significance }\end{array}$ & $\begin{array}{c}5.42 \pm 0.38 \\
\text { None }\end{array}$ & $\begin{array}{c}19.16 \pm 2.42 \\
18.96 \pm 2.06 \\
99 \% \\
\text { NS }^{*}\end{array}$ & $\begin{array}{c}3.123 \pm 0.358 \\
3.002 \pm 0.237 \\
96 \% \\
\text { NS }\end{array}$ & $\begin{array}{c}0.416 \pm 0.034 \\
0.336 \pm 0.051 \\
77 \% \\
p=0.0097\end{array}$ & $\begin{array}{c}1.560 \pm 0.265 \\
1.492 \pm 0.251 \\
96 \% \\
\text { NS }\end{array}$ & $\begin{array}{c}1.054 \pm 0.080 \\
1.031 \pm 0.072 \\
98 \% \\
\text { NS }\end{array}$ \\
\hline $\begin{array}{l}\text { Experiment B } \\
\begin{array}{l}45-50 \text { days ( } n \\
=6 \text { pairs })\end{array}\end{array}$ & $\begin{array}{l}\text { Control } \\
\text { Experimental } \\
\% \text { Control } \\
\text { Significance }\end{array}$ & $\begin{array}{c}3.65 \pm 1.52 \\
\text { None }\end{array}$ & $\begin{array}{c}33.42 \pm 2.52 \\
32.63 \pm 4.41 \\
98 \% \\
\text { NS }\end{array}$ & $\begin{array}{c}3.417 \pm 0.380 \\
3.375 \pm 0.626 \\
99 \% \\
\text { NS }\end{array}$ & $\begin{array}{c}0.884 \pm 0.064 \\
0.622 \pm 0.057 \\
70 \% \\
p=0.00001\end{array}$ & $\begin{array}{c}2.230 \pm 0.389 \\
2.108 \pm 0.562 \\
95 \% \\
\text { NS }\end{array}$ & $\begin{array}{c}1.601 \pm 0.105 \\
1.613 \pm 0.070 \\
101 \% \\
\text { NS }\end{array}$ \\
\hline $\begin{array}{l}\text { Experiment } C \\
50-55 \text { days }(n \\
=5 \text { pairs })\end{array}$ & $\begin{array}{l}\text { Control } \\
\text { Experimental } \\
\% \text { Control } \\
\text { Significance }\end{array}$ & $\begin{array}{c}2.01 \pm 1.14 \\
\text { None }\end{array}$ & $\begin{array}{c}52.62 \pm 2.92 \\
53.61 \pm 4.44 \\
102 \% \\
\text { NS }\end{array}$ & $\begin{array}{c}4.959 \pm 0.461 \\
4.727 \pm 0.643 \\
95 \% \\
\text { NS }\end{array}$ & $\begin{array}{c}1.209 \pm 0.077 \\
1.079 \pm 0.109 \\
89 \% \\
p=0.0307\end{array}$ & $\begin{array}{c}3.588 \pm 0.506 \\
3.735 \pm 0.312 \\
104 \% \\
\text { NS }\end{array}$ & $\begin{array}{c}1.920 \pm 0.114 \\
2.114 \pm 0.077 \\
110 \% \\
p=0.0069\end{array}$ \\
\hline $\begin{array}{l}\text { Experiment D } \\
\quad 40-50 \text { days ( } n \\
=6 \text { pairs) }\end{array}$ & $\begin{array}{l}\text { Control } \\
\text { Experimental } \\
\% \text { Control } \\
\text { Significance }\end{array}$ & $\begin{array}{c}3.53 \pm 1.33 \\
\text { None }\end{array}$ & $\begin{array}{c}36.43 \pm 2.79 \\
31.30 \pm 3.07 \\
86 \% \\
p=0.0058\end{array}$ & $\begin{array}{c}3.544 \pm 0.698 \\
3.340 \pm 0.334 \\
94 \% \\
\text { NS }\end{array}$ & $\begin{array}{c}0.928 \pm 0.107 \\
0.441 \pm 0.071 \\
48 \% \\
p=0.00001\end{array}$ & $\begin{array}{c}2.288 \pm 0.360 \\
2.012 \pm 0.465 \\
88 \% \\
\text { NS }\end{array}$ & $\begin{array}{c}1.729 \pm 0.095 \\
1.644 \pm 0.145 \\
95 \% \\
\text { NS }\end{array}$ \\
\hline $\begin{array}{l}\text { Experiment } \mathrm{E} \\
\begin{array}{l}45-55 \text { days ( } n \\
=6 \text { pairs) }\end{array}\end{array}$ & $\begin{array}{l}\text { Control } \\
\text { Experimental } \\
\% \text { Control } \\
\text { Significance }\end{array}$ & $\begin{array}{c}2.67 \pm 0.89 \\
\text { None }\end{array}$ & $\begin{array}{c}53.34 \pm 3.20 \\
49.02 \pm 6.89 \\
92 \% \\
\text { NS }\end{array}$ & $\begin{array}{c}4.866 \pm 0.736 \\
4.417 \pm 1.032 \\
91 \% \\
\text { NS }\end{array}$ & $\begin{array}{c}1.191 \pm 0.140 \\
0.787 \pm 0.170 \\
66 \% \\
p=0.0006\end{array}$ & $\begin{array}{c}3.607 \pm 0.408 \\
3.307 \pm 1.036 \\
92 \% \\
\text { NS }\end{array}$ & $\begin{array}{c}1.913 \pm 0.180 \\
1.984 \pm 0.150 \\
104 \% \\
\text { NS }\end{array}$ \\
\hline
\end{tabular}

NS with $p>0.05$.

Table 2. Fetal lung growth: effect of timing and duration of oligohydramnios ( $m$ g of lung DNA per $g$ of fetal wt, mean $\pm S D$ )

\begin{tabular}{|c|c|c|c|c|c|}
\hline Gestation & Control & Experimental & $\begin{array}{l}\% \text { of } \\
\text { control }\end{array}$ & $\delta$ & $\begin{array}{l}\text { Paired } t \\
\text { test }\end{array}$ \\
\hline \multicolumn{6}{|l|}{ Short term ( 5 days) } \\
\hline $\begin{array}{l}\text { Experiment A } \\
\text { days } 40-45 \text { ( } n=5 \text { pairs from } 4 \text { litters })\end{array}$ & $0.186 \pm 0.012$ & $0.138 \pm 0.011$ & 74 & 0.047 & $\begin{array}{l}t=6.14 \\
p=0.0036\end{array}$ \\
\hline $\begin{array}{l}\text { Experiment B } \\
\text { days } 45-50 \text { ( } n=6 \text { pairs from } 5 \text { litters })\end{array}$ & $0.173 \pm 0.013$ & $0.131 \pm 0.009$ & 76 & 0.042 & $\begin{array}{l}t=6.20 \\
p=0.0016\end{array}$ \\
\hline $\begin{array}{l}\text { Experiment } C \\
\quad \text { days } 50-55 \text { ( } n=5 \text { pairs from } 4 \text { litters })\end{array}$ & $0.182 \pm 0.012$ & $0.156 \pm 0.018$ & 86 & 0.027 & $\begin{array}{l}t=2.16 \\
p=0.0966\end{array}$ \\
\hline \multicolumn{6}{|l|}{ Long term ( 10 days $)$} \\
\hline $\begin{array}{l}\text { Experiment } \mathrm{D} \\
\text { days } 40-50 \text { ( } n=6 \text { pairs from } 4 \text { litters) }\end{array}$ & $0.191 \pm 0.016$ & $0.119 \pm 0.019$ & 62 & 0.072 & $\begin{array}{l}t=8.40 \\
p=0.0004\end{array}$ \\
\hline $\begin{array}{l}\text { Experiment } \mathrm{E} \\
\quad \text { days } 45-55 \text { ( } n=6 \text { pairs from } 4 \text { litters) }\end{array}$ & $0.178 \pm 0.010$ & $0.132 \pm 0.011$ & 74 & 0.047 & $\begin{array}{l}t=6.35 \\
p=0.0014\end{array}$ \\
\hline
\end{tabular}

\section{DISCUSSION}

Oligohydramnios in the guinea pig leads to a selective pattern of fetal growth retardation with a predominant impact on lung growth and sparing other organs. We have described a similar pattern in three other species (rat, sheep, human) $(8,11,17)$ and lung hypoplasia has been documented by others following drainage or aspiration of amniotic fluid in the rabbit and the monkey $(9,10)$. This cumulative evidence suggests that normal amniotic fluid volume is a universal determinant of lung growth in the mammalian fetus. The possible ways by which amniotic fluid allows for normal fetal lung growth are many and their presentation is bcyond the scope of this discussion (18). At this point, it is difficult to determine whether, in addition to lack of amniotic fluid itself, other mechanisms may have contributed to impaired fetal lung growth in our experiment. The design of the experiment allows control for maternal factors (anesthesia, laparotomy, temporarily reduced caloric intake) since experimental fetuses were compared to littermates. The stress imposed on the experimental fetus by creating an amnioperitoneal fistula, acutely draining amniotic fluid and possibly altering uteroplacental per- fusion is difficult to control for. However, it is thought that chronic fetal stress impairs more, or at least equally, fetal liver than fetal lung growth, leading to a pattern of fetal growth retardation different from the one observed in our experiment (19-21). We found no evidence of fetal infection by histological examination of the placentas.

Our results demonstrate that fetal lung growth in the guinea pig is inhibited by a short period of oligohydramnios ( 5 days or $7-8 \%$ of gestation), and that the effect is significantly more pronounced during the canalicular stage of lung development. Using an analysis of variance, we documented that the magnitude of the change between the various experiments (i.e. the different time frames in gestation) was related to both the time of onset and the duration of oligohydramnios. Although we found that the earlier the onset and the longer the duration of oligohydramnios, the more marked was the effect on lung growth, these relationships were compounded by another factor not known at the time of the study design.

We recently documented that the fetal guinea pig lung is in the canalicular stage of development by 40 days and that the terminal sac stage extends between day 50 and term (67 days) 
(13). Considering the effect of oligohydramnios on lung growth and differentiating between canalicular and terminal sac stages, the following observations can be made. 1) The impact of 5 days duration is similar in the second third and the last third of the canalicular stage (i.e. experiments $\mathrm{A}$ and B). 2) The impact of 10 days duration during the canalicular stage (experiment D) appears cumulative, with the magnitude of the change approximating the sum of the changes seen in two consecutive 5-day periods (experiments $A$ and $B$ ). However, this observation is not as clean as may appear at first glance. The values for lung DNA per gram of fetus for the controls in all five experiments vary between 0.172 and 0.191 (see Table 2) and the values for the controls at 50 days (experiments B and D) represent the extremes of this distribution. This disparity between control values could significantly impact on the validity of the above conclusions (cumulative effect). If one were to assume that lung DNA/g fetus does not vary for controls at the gestational ages studied, the value for the mean of all five study periods would be 0.182 (which is also the mean for both control groups at day 50). Using this new mean control value, the impact of 10 days of oligohydramnios during the canalicular stage $(D, \delta$ of 0.063$)$ is less than the sum of the changes seen during two consecutive 5-day periods (A, $\delta$ of $0.043 ; \mathrm{B}, \delta$ of 0.049 ). 3) The impact of 5 days of oligohydramnios during the terminal sac stage although not negligible, is significantly less than that resulting from the same duration of insult in the canalicular stage. 4) The impact of a 10day period including 5 days of late canalicular and 5 days of early terminal sac stage (experiment E) appears to be predominantly the result of interference with lung growth during the canalicular stage of lung development (i.e. magnitude of change is similar to that seen in experiment B). This was verified by the two-way analysis of variance.

Traditionally, prolonged rupture of the membranes occurring in a preterm pregnancy has been thought to present a dilemma in obstetrical management because of the risk of infection and reduced chances of fetal survival associated with prematurity. Unless evidence of infection develops, the current trend is for conservative management. However, recent clinical evidence suggests that another threat should be considered when rupture of the membranes leads to oligohydramnios, i.e. fetal lung hypoplasia $(22,23)$. Clinically we are particularly interested in what happens to lung growth with oligohydramnios during the canalicular to early terminal sac stages of lung development. This period extends between the time when early diagnosis of oligohydramnios can be made by ultrasound and the gestational age of 28 to $30 \mathrm{wk}$, when good chances for intact extrauterine survival can be expected.

Although great caution must be used before information obtained with animal models can be extrapolated to humans, our results are compatible with a recent clinical study. Nimrod et al. (22) observed that both gestational age at rupture and length of the latent period (until delivery) were associated with lung hypoplasia, particularly below 26 wk of gestation. Of note, Thibeault et al. (23) observed that lung hypoplasia was "relatively common" in infants born prematurely with ruptured membranes for more than 5 days.

In summary, we have presented an animal model of oligohydramnios-induced lung hypoplasia and demonstrated that even short periods (7-8\%) of gestation without amniotic fluid impair lung growth. This effect was greatest during the canalicular stage but was still noticeable (yet not statistically significant) during the terminal sac stage of lung development.

Acknowledgments. The authors thank Mr. Frank Mallavo for his expert technical assistance, Ms Yvonne Wang for the DNA determination, and Dr. Angelita Santiago for her assistance with the manuscript preparation.

\section{REFERENCES}

1. Wigglesworth JS, Desai R 1982 Is fetal respiratory function a major determinant of perinatal survival? Lancet 1:264-267

2. Moessinger AC, Abbey-Mensah M, Driscoll JM, Blanc WA 1983 Pulmonary hypoplasia, a disorder on the rise? Pediatr Res 17:372(abstr)

3. Page DV, Stocker JT 1982 Anomalies associated with pulmonary hypoplasia. Am Rev Respir Dis 125:216-221

4. Swischuk LE, Richardson CJ, Nichols MM, Ingman MJ 1979 Pulmonary hypoplasia in the neonate. J Pediatr 95:573-577

5. Thomas IT, Smith DW 1974 Oligohydramnios, cause of the nonrenal features of Potter's syndrome, including pulmonary hypoplasia. J Pediatr 84:811-14

6. Blanc WA, Apperson JW, McNally J 1962 Pathology of the newborn and of the placenta in oligohydramnios. Bull Sloane Hosp Women 8:57-64

7. Bain AO, Smith II, Gauld IK 1964 Newborn after prolonged leakage of liquor amnii. Br Med J 2:598-599

8. Moessinger AC, Bassi GA, Balantyne G, Collins MH, James LS, Blanc WA 1983 Experimental production of pulmonary hypoplasia following amniocentesis and oligohydramnios. Early Hum Dev 8:343-350

9. Nakayama DK, Glick PL, Harrison MR, Villa RL, Noall R 1983 Experimental pulmonary hypoplasia due to oligohydramnios and its reversal by relieving thoracic compression. J Pediatr Surg 18:347-353

10. Hislop A, Fairweather DVI, Blackwell RJ, Howard S 1984 The effects of amniocentesis and drainage of amniotic fluid on lung development in macaca fascicularis. Br J Obstet Gynaecol 91:835-842

11. Moessinger AC, Fewell JE, Stark RI, Collins MH, Daniel SS, Singh M, Blanc WA, Kleinerman J, James LS 1985 Lung hypoplasia and breathing movements following oligohydramnios in fetal lambs. In: Jones C, Nathanielsz P (eds) The Physiological Development of the Fetus and Newborn. Academic Press, London, pp 293-298

12. Moessinger AC, Collins MH, Blanc WA, Kleinerman J, James LS 1984 Oligohydramnios-induced lung hypoplasia: influence of timing and duration (animal model). Pediatr Res 18:336(abstr)

13. Collins MH, Kleinerman J, Moessinger AC, Collins AM, James LS, Blanc WA 1986 Morphometric analysis of the growth of the normal fetal guinea pig lung. Anat Rec (in press)

14. Adolf EF 1967 Ontogeny of volume regulations in embryonic extracellular fluids. Q Rev Biol 42:1-39

15. Munro HN, Fleck A 1966 Recent developments in the measurements of nucleic acids in biological material. Analyst 91:78-88

16. Draper RL 1920 The prenatal growth of the guinea pig. Anat Rec 18:369-392

17. Naeye RL, Blanc WA 1972 Fetal renal structure and the genesis of amniotic fluid disorders. Am J Pathol 67:97-108

18. Kitterman JA 1986 Physical factors and fetal lung growth. In: Johnston BM. Gluckman PD (eds) Respiratory Control and Lung Development in the Fetal and Newborn. Perinatology Press, Ithaca, NY pp 63-85

19. Barcroft J 1947 Researches on Prenatal Life. Charles C Thomas, Springfield, IL

20. Blanc WA 1969 The future of antepartum morphological studies. In: Adamson K (ed) Treatment of Fetal Disorders. Springer Verlag, New York, pp 15-49

21. Gruenwald P 1974 Pathology of the deprived fetus and its supply line. In: Ciba Foundation Symposium 27, Size at Birth. Elsevier-Exerpta Medica-North Holland, New York, pp 3-19

22. Nimrod C, Varela-Gittings F, Machin G, Campbell D, Wesenberg R 1984 The effect of very prolonged membrane rupture on fetal development. Am J Obstet Gynecol 148:540-43

23. Thibeault DW, Beatty EC Jr, Hall RT, Bowen SK, O'Neill DH 1985 Neonatal pulmonary hypoplasia with premature rupture of fetal membranes and oligohydramnios. J Pediatr 107:273-277 